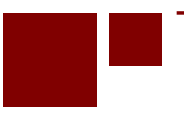

C E N T E R for RETIREMENT RES E A R C H at BOSTON COLLEGE

\title{
WOULD REDUCING THE PRICE OF EMPLOYING AN OLDER WORKER IMPROVE LABOR MARKET OUTCOMES BY SOCIOECONOMIC STATUS? EVIDENCE FROM HEALTH INSURANCE PREMIUM RESTRICTIONS
}

\author{
Matthew S. Rutledge and Caroline V. Crawford
}

CRR WP 2016-17

December 2016

\author{
Center for Retirement Research at Boston College \\ Hovey House \\ 140 Commonwealth Avenue \\ Chestnut Hill, MA 02467 \\ Tel: 617-552-1762 Fax: 617-552-0191 \\ http://crr.bc.edu
}

Both authors are with the Center for Retirement Research at Boston College (CRR). Matthew S. Rutledge is a research economist at the CRR. Caroline V. Crawford is a research associate at the CRR. The research reported herein was pursuant to a grant from the Alfred P. Sloan Foundation. The findings and conclusions expressed are solely those of the authors and do not represent the views of the Alfred P. Sloan Foundation or Boston College.

(c) 2016, Matthew S. Rutledge and Caroline V. Crawford. All rights reserved. Short sections of text, not to exceed two paragraphs, may be quoted without explicit permission, provided that full credit, including $(\subset$ notice, is given to the source. 


\begin{abstract}
About the Center for Retirement Research
The Center for Retirement Research at Boston College, part of a consortium that includes parallel centers at the University of Michigan and the National Bureau of Economic Research, was established in 1998 through a grant from the Social Security Administration. The Center's mission is to produce first-class research and forge a strong link between the academic community and decision-makers in the public and private sectors around an issue of critical importance to the nation's future. To achieve this mission, the Center sponsors a wide variety of research projects, transmits new findings to a broad audience, trains new scholars, and broadens access to valuable data sources.
\end{abstract}

\author{
Center for Retirement Research at Boston College \\ Hovey House \\ 140 Commonwealth Ave \\ Chestnut Hill, MA 02467 \\ Tel: 617-552-1762 Fax: 617-552-0191 \\ http://crr.bc.edu
}

Affiliated Institutions:

The Brookings Institution

Syracuse University

Urban Institute 


\begin{abstract}
Delaying retirement improves retirement preparedness, but older workers cannot work longer if employers do not hire or retain them. This study examines one way in which public policy potentially makes older workers more attractive to employers: state regulatory restrictions on how much employer premiums are permitted to increase at small firms with older, unhealthier workforces. The study uses data from the Current Population Survey from 1989-2013 to compare older individuals' overall employment, small-firm employment, and earnings in states with varying degrees of premium regulation, and among workers of different educational backgrounds. The analysis shows mixed results. Stronger premium regulations were not effective in increasing employment: employment at small firms, which are most sensitive to premium increases, saw no statistically significant increase, and overall employment for older workers at both large and small firms increased only slightly. The earnings gap between large and small firms is also smaller in states with tighter restrictions, but older workers were not helped appreciably more than younger workers. These results suggest that indirect efforts to lower the price of hiring an older worker are not likely to be effective in improving their job prospects.
\end{abstract}




\section{Introduction}

Older workers appear to be getting the message that they need to work longer: the average retirement age has increased by about two years over the past two decades (Munnell 2015). Labor force participation rates for older individuals continued to climb even during the Great Recession, when a greater proportion of older Americans were out of work, and for longer spells, than ever before (Munnell and Rutledge 2013). But participation rate increases without employment increases indicate an excess supply for older workers at prevailing wages. Will these workers looking to extend their careers be able to find jobs? The question is particularly relevant for less-educated workers who rely on middle-skill jobs. They already have more difficulty finding work in their prime (Autor 2014). What can policymakers do to ensure that less-educated workers looking to stay in the workforce are attractive to potential employers?

Some economists have proposed policies that make older workers less expensive than younger workers, such as making Medicare the primary payer or allowing workers with 40 years

of contributions to Social Security to be considered "paid up,” which might encourage employers to hire older people (e.g., Goda, Shoven, and Slavov 2007, 2009). These policies sound promising, but have yet to be tried in the United States, and are not particularly targeted toward older workers of lower socioeconomic status.

One policy that has been tried in the United States is restricting how much employersponsored health insurance premiums can vary across firms. Hiring older workers, with their greater expected health costs, can raise employers' health benefit expenditures. This concern is especially acute at small firms, where adding one high-risk employee to the pool has a more substantial effect on average costs, and hence the firm's premiums, than at large firms.

Partly with this concern in mind, nearly every state passed regulations in the 1990s restricting how much premiums could vary across firms. These regulations effectively lower the price of hiring an additional older worker by reducing how much each new worker can affect health insurance expenditures for their employer. These regulations were expected to boost labor demand for older workers by lowering their benefit costs and increase labor supply by improving access to employer-sponsored health insurance.

This study examines whether these premium restrictions improved employment and earnings for the workers most directly affected: older employees at small firms. The results are 
also presented for workers of different educational backgrounds to establish who, if anyone, was helped. The rollout of these regulations was gradual, and differed substantially across states, providing a natural experiment to evaluate how employers

(and their potential employees) respond to exogenous changes in the price of employing one more older worker. This evaluation required painstaking collection of nearly 25 years of premium regulations from state commercial codes and disparate policy analyses. This database of premium regulations is merged with household data from the Current Population Survey (CPS) Annual Social and Economic Supplement conducted each March.

The results are decidedly mixed. Overall, older workers are slightly more likely to be employed in states with stronger premium restrictions, but not at the firms most affected by the regulations: small employers. The results are more positive with regard to another measure of the attractiveness of workers to employers: earnings. The premium regulations did help close the gap in earnings between all workers at large and small firms, which suggests that stronger regulations helped small firms make more competitive wage offers. There is some evidence that the gap closes by more for older workers but it is fairly weak.

The estimated effects differ by educational attainment. Older individuals with only a high school degree appear to benefit most consistently from premium restrictions - they see increases in both overall employment rates and small-firm earnings (relative to workers at large firms). Older high school dropouts at small firms are able to substantially close the earnings gap with their counterparts at large firms, but the effect on their employment rate is slightly negative. The opposite is true for college graduates: their overall employment rate increases (though not especially at small firms) while their large-to-small-firm earnings gap appears unaffected. But none of these groups saw an increase in small-firm employment, which had been the anticipated effect.

The paper is structured as follows. Section 2 provides background on premium restrictions. Section 3 reviews two spheres of the economic literature: studies that examine how the price of hiring another older worker affects this group’s labor market outcomes, and studies that review the effects of premium restrictions and community rating. Section 4 describes the data and outlines the econometric model. Section 5 reviews the results. Section 6 concludes that restrictions on small-group health insurance premiums did little to make older workers more 
attractive to potential employers, which suggests that more direct wage subsidies might be needed to improve their labor market outcomes.

\section{Employer-Sponsored Health Insurance Premium Regulations}

One of the main deterrents in hiring an older worker is the possibility of an increase in their employer's health care premiums by insurance companies. Age and health status are commonly used to increase premium costs as older and less healthy people are more likely to use medical services. Historically, insurance companies have been able to increase group premium costs based on demographic characteristics. However, over the years, state and federal restrictions have been imposed that reduce the degree to which this discrimination can occur.

Given the large role that employer-sponsored health insurance plays in the private sector, it is essential to consider premiums when discussing discrimination against older workers. The popularity of employer-sponsored insurance is largely due to its ability to spread health costs and risk among a group of people. A subset of employer-sponsored insurance is the small-group market, consisting of employer groups ranging from 2 to 50 employees. Due to their size, employers in the small-group market are less able to spread risk among employees, thereby increasing insurance costs. This smaller, and more volatile, risk pool makes insurance companies less inclined to offer coverage to employers and employers less inclined to provide benefits to their employees. Federal and state governments have enacted regulations in the small-group market to make health coverage more accessible and affordable. Yet smaller employers remain less likely to offer health benefits to their employees.

Early age discrimination laws focused on protecting older workers in interactions with employers more generally, rather than focusing on health costs in particular. The federal Age Discrimination in Employment Act (ADEA), passed in 1967, prohibited employers from making hiring, discharging, and compensation decisions based on employee age. ${ }^{1}$ Initially the ADEA applied to employees ages 40-65; it was expanded in 1978 to include employees up to age 70 and was extended to all workers ages 40 or older in 1987. The ADEA was enacted with the goal of reducing long-term unemployment among older workers. Notwithstanding the progress made by the ADEA, it did not impose any requirements on employee benefits, such as health insurance.

129 U.S.C. § 621 
Our discussion with industry insiders suggest that, within any one firm, employees have almost always paid the same premium for the same plan. This idea was codified in two federal laws in the 1990s. The 1990 Older Workers Benefit Protection Act (OWBPA) amended the ADEA to include an "equal cost or equal benefit” provision. ${ }^{2}$ Under this provision, employers do not violate the ADEA if they pay the insurance provider the same amount per employee, even if that causes the older worker's premium contribution to increase or to have lesser benefits than a younger employee. ${ }^{3}$

The restriction on within-firm premium differences was made even stronger in 1996 by the federal Health Insurance Portability and Accountability Act (HIPAA). This law mandated an employer charge all individuals in a group health plan the same premium regardless of health status. ${ }^{4}$ In addition, HIPAA required small-group, employer-sponsored health plans to adopt guaranteed issue and guaranteed renewal provisions. Guaranteed issue policies require insurers to offer access to health plans to all employers, regardless of the group’s health status. Without a guaranteed issue policy, commercial insurers could refuse to cover groups with greater medical needs. Guaranteed renewal policies prevent insurers from cancelling coverage for a group based on their past medical claims or new diagnoses. By 1999, all states (except California) had adopted policies that complied with HIPAA. ${ }^{5}$

While HIPAA prohibited premium differences among the employees in an individual firm, it does not regulate how premiums may vary across firms, which means that an employer is not protected from a premium increase for all its workers if unhealthy employees are added to the group. Up until the early 1990s, insurance companies set premiums for employer-sponsored health insurance plans using the characteristics of the firm's employees. Firms with a history of, or the prospect for, greater costs were charged more. Between 1990 and 1994, 45 states passed legislation to prevent drastic premium increases caused by medical underwriting.

Some states adopted "community rating” policies that prohibit insurers from varying premium costs for different firms due to any firm's employee characteristics. Pure community rating policies force a plan to charge the same per-enrollee premium, regardless of the underlying characteristics of employees at each firm; the insurer charges every firm with a group

\footnotetext{
229 U.S.C. $\S \S 623,626,630$

3 See EEOC Compliance Manual.

${ }^{4} 42$ USC $\$ 702$

${ }^{5}$ See U.S. DHHS (2000).
} 
plan the same average per-enrollee cost. Other states adopted modified community rating policies, which prohibit the use of underwriting based on health status, but permit premium variation for other group characteristics such as age, gender, tobacco use, industry class, geographic area, or family composition.

Alternatively, the majority of states adopted rate-band policies, which allow the insurer to vary premiums based on group characteristics, including health status, subject to limitations. These provisions establish an acceptable range of premiums that an insurer can charge the most and least risky groups. For example, a rate-band ratio of 3:1 restricts the largest group premium to three times the base rate.

These laws were passed with the goal of standardizing health insurance premiums charged to small employer groups. When states began to pass legislation in the early 1990s, the National Association of Insurance Commissioners (NAIC) developed a model that states were encouraged to adopt. NAIC regulations prohibited rating by health status, imposed a 1.67:1 rateband ratio for all other factors, ${ }^{6}$ and required guaranteed issue and guaranteed renewal provisions. A large proportion of states opted to implement NAIC provisions. However, NAIC lacked authority to enforce any of its guidelines, and legislation continued to be passed between 1990 and 2013 that further refined the laws on a state-by-state basis.

In 2014, the Affordable Care Act (ACA) standardized rating restrictions nationally by prohibiting the use of health status and restricting rating by age to a 3:1 ratio. Until this point, states had held sole regulatory authority over rating restriction laws. Therefore, from 1989, when no states had enacted rating restriction policies, to 2013, the final year before federal oversight, insurance premiums varied widely depending on the state in which the insurer provided coverage. This research examines only state rating restrictions enacted prior to the ACA's national restrictions.

\section{Previous Literature}

The relevant literature covers two main topics: 1) the price of hiring and employing another older worker; and 2) the effect of premium restrictions on health insurance markets and labor market outcomes.

\footnotetext{
${ }^{6}$ A 1.67:1 ratio is the equivalent of allowing premiums to vary by plus or minus 25 percent. If premiums are $\$ 100$ per month for a moderate-risk firm, they could be as high as $\$ 125$ for a high-risk firm, or $\$ 75$ for a low-risk firm. The ratio of high- to low-risk firms' premiums is $125 / 75=1.67$.
} 
Price of Older Workers. Even as efforts to encourage longer work lives appear to be working, a major concern is whether demand for older workers will keep up with the growing supply. One way to increase demand is to lower the effective price of labor. Economists have proposed wage subsidies in other contexts to encourage hiring, most notably in the slow recovery from the Great Recession. ${ }^{7}$ Adapting and extending these subsidies to other groups who may face reluctance in the hiring market - in this case, older workers - may make sense.

Several countries have tried wage subsidies for older, usually lower-wage, workers with mixed results. Subsidies in Finland (Huttunen et al. 2010), Germany (Boockmann et al. 2007, Schunemann et al. 2011), and Spain (Garcia-Perez and Sanz 2009) have had minimal effects on employment. But Austria's wage subsidies - targeted at the long-term unemployed - have been more successful in reducing the length of unemployment spells, with the largest effects among older job-seekers (Eppel and Mahringer 2012). ${ }^{8}$

Economists studying potential policies for older Americans tend to focus less on direct wage subsidies, and more on the parameters of Social Security and Medicare that, if reformed, would act as a subsidy. One option is to reduce the implicit tax on wages for older workers by allowing them to opt out of the payroll tax (and associated benefit increases) at some point after the Full Retirement Age (Burtless and Quinn 2002). A slight variation of this idea is to automatically consider workers with 40 years of earnings contributions over some minimum threshold to be "paid up" (Goda, Shoven, and Slavov 2009). Beyond that point, neither employees nor employers would have to pay their share of the payroll tax. This policy has not been tried, so the analysis in previous research is limited to simulations of its potential effect, rather than empirical evaluations in a real-world setting.

Several studies point out that Medicare's second-payer status artificially increases the cost of employing Medicare-eligible employees, who employers nonetheless are required to include in their health insurance plans (Glied and Stabile 2001, Johnson 2003, and Goda, Shoven, and Slavov 2007). These employees would be willing to work for lower total

\footnotetext{
${ }^{7}$ This suggestion serves as an alternative to the more contentious prospect of raising the minimum wage, and has been championed by both left- and right-of-center economists (Blinder 2010; Delong 2010; Glaeser 2013; Pethokoukis 2013). Several tax credits were passed as part of stimulus bills during 2009-2010, including the Hiring Incentives to Restore Employment (HIRE) Act, which eliminated employers' payroll tax contribution for new employees in 2010. But take-up was limited (Klein 2010), and its nationwide implementation makes identifying its impact difficult. Heaton (2012), however, finds a statistically significant increase in employment among disabled veterans eligible for hiring tax credits under the Work Opportunity Tax Credit.

${ }^{8}$ Taylor (2002) cites similar programs that target the near-elderly in Japan and Australia.
} 
compensation - demonstrated by the fact that they work, even though the insurance benefit is of only marginal value to them given the Medicare backstop - but the cost to the employer is the same as it is for workers who are under 65. Johnson (2003) suggests that making Medicare the primary payer would save as much as $\$ 1,500$ per Medicare-eligible worker; while the savings is only about 4 percent of the median salary, the fixed cost of insurance is a much higher share of labor costs for lower-wage workers. Two studies find only mixed effects of second-payer status on employment and wages, but each study faces a substantial barrier: Glied and Stabile's (2001) results are complicated by lax enforcement of the second-payer status before 1995, and Goda, Shoven, and Slavov's (2007) estimates are confounded by coincidental earnings test changes.

This study uses a different natural experiment - the adoption of premium restrictions in the small-group market - to estimate the effects on employment and earnings directly under a policy change that has predicted effects similar to direct wage subsidies. This natural experiment was implemented at different times in different states and strictly enforced, and thus should be able to avoid the pitfalls faced by the two studies on Medicare as a second-payer. ${ }^{9}$

Effect of Premium Restrictions. The adoption of community rating and other regulations of employer-sponsored health insurance premiums have received a great deal of attention in the economics literature, because their state-by-state rollout provides the setting for a natural experiment.

Most of this literature has focused on adverse selection - that is, reducing the information on which insurers can set premiums reduces coverage among low-risk groups (in this case, younger, healthier workers) or reduces coverage rates altogether (i.e., the market’s “death spiral”). After New York adopted pure community rating, Buchmueller and DiNardo (2002) find, the age distribution in the risk pool shifted more toward older employees than in the control state of Pennsylvania. Their focus is on this shift as evidence of adverse selection, but it is also consistent with greater employment among older workers. Still, their analysis of the labor market effects is limited to only three states. Monheit and Schone (2003) and Simon (2005)

\footnotetext{
${ }^{9}$ An existing U.S. program, Alternative Trade Adjustment Assistance, provides wage subsidies to displaced workers ages 50 and over who find re-employment at jobs paying less than $\$ 50,000$ per year. The subsidy is equal to half of the difference between their old and new jobs, up to \$10,000, paid over a two-year period (U.S. Department of Labor: http://www.doleta.gov/tradeact/benefits.cfm). Research on the effects of the program appears to be scant (Baicker and Rehavi 2004), perhaps because the program is small.
} 
focus on how employer-sponsored health insurance coverage responds to premium regulation, rather than the response in employment outcomes, but use a difference-in-differences methodology similar to ours. ${ }^{10}$

Although these studies do not focus on employment outcomes, they indicate that the wage-cost differential or older workers is potentially substantial. Adams (2007) estimates that New York's adoption of pure community rating reduced the young-vs-old health cost gap by \$2.08 per worker-hour in 1993 dollars (half of that from rising premiums for young workers and half from falling premiums for older workers); that is the equivalent of $\$ 3.35$ per worker-hour in 2013 dollars, or 14 percent of the mean hourly wage of \$24.15 in November 2013.

A smaller group of studies examine the employment effects of small-group health reform. Kaestner and Simon (2002) find no statistically significant effects on the number of weeks worked, wages, or employment in small vs. large firms. But this study did not focus on the higher-risk employees most likely to be directly affected by the small-group premium regulation. Kapur (2004) examines the difference in employment of unhealthy workers in small firms (relative to large firms, in a multinomial logit model) before the reforms (in 1987) and after the reforms (in 1996). She finds that labor market outcomes differ by health conditions: in 1987, small-firm employment is lower for workers with health conditions associated with high premiums, but, in 1996, the only conditions associated with lower small-firm employment are those that would lead the insurer to deny coverage altogether, since the insurers lost the recourse of raising premiums for the riskiest policyholders.

The closest study to ours is Kapur (2003), which finds that small firm hiring rose for workers with an unhealthy family member also covered by their plan but that hiring fell for older workers. Our study differs in several important ways. Kapur's study uses data from 1990-1998; ours updates the database of premium regulations through just prior to implementation of the ACA in 2013. Kapur also groups health insurance regulations into discrete categories based on strength; our econometric specification allows for a continuous relationship between the premium rate band and labor market outcomes. In addition, our econometric model focuses on older workers, rather than on the unhealthy - though the results for health presented in the

\footnotetext{
${ }^{10}$ Other studies have examined how community rating affects the individual health insurance market (e.g., Lo Sasso and Lurie 2009). While individual buyers of health insurance might have a different reservation wage than those who are seeking a job with health insurance benefits, their cost to a potential employer is no different ex-ante, as the employer has to offer them health insurance if they offer plans to other employees.
} 
robustness check section are similar. Our model also includes state fixed effects to capture differences among states that passed regulations of various strength. ${ }^{11}$ Importantly, our study examines the potential consequences of premium restrictions on total employment and earnings, not just on small-firm employment. ${ }^{12}$ Our study also includes an analysis of the heterogeneity of the relationship between premium regulation and labor market outcomes by educational attainment.

\section{Data and Methodology}

The paper uses data from the March Annual Social and Economic Supplement (ASEC) of the Current Population Survey (CPS) for 1990-2014, which covers the 1989-2013 calendar years. The analysis is limited to individuals between ages 25-61 to capture the working-age population. It also excludes respondents living in Hawaii (a sample of 31,161 individuals), due to the state's unique health insurance legislation. ${ }^{13}$ These criteria cut our CPS sample from $8,292,837$ to $2,180,797$ observations.

The research questions pertain to whether residents of states with small-group premium restrictions have better labor market outcomes; whether those outcomes differ for workers at small vs large firms; and whether those outcomes by firm size differ for workers by socioeconomic status (SES). The proxy for SES is a categorical variable for educational attainment: 1) less than a high school degree; 2) a high school degree and no more; 3) some college experience without a four-year degree; or 4) at least a college degree. Some studies point out that the falling share of the population with less than a high school degree over the $20^{\text {th }}$ century has altered the underlying health and, thus, the employability of this group (Bound, Geronimus, and Rodriguez 2014; Sanzenbacher et al. 2015). But most of the change in educational attainment occurred for earlier cohorts than ours; the share of our sample with less than a high school degree is roughly constant at 4-7 percent throughout the 1989-2013 period.

\footnotetext{
${ }^{11}$ Kapur (2003) reports that her results are robust to the inclusion of state-specific trend variables; it is not clear if this specification duplicates the state fixed effects in our model.

${ }^{12}$ Kapur (2003) focuses on small-firm hiring, not small-firm employment more generally. That study also includes job mobility as a dependent variable, to determine whether premium restrictions eased "job lock" - the idea that workers stay in a suboptimal job to avoid putting their health insurance coverage at risk. Kapur finds evidence that job mobility is eased for workers with unhealthy family members, but not for older workers.

${ }^{13}$ Hawaii passed its Prepaid Health Care (PHC) Act in 1974, the first piece of state legislation that set minimum standards for employee health care coverage. In short, the Act required employers to provide health insurance to all eligible employees. Due to its PHC Act, Hawaii is the only state which has been exempted from ERISA provisions. For this reason, any amendments to Hawaii's state health insurance laws must go through federal court.
} 
To examine how small-group premium restrictions relate to employment outcomes, our study requires comprehensive data on state rate-restriction laws. We compiled a dataset tracking the active premium restriction policies in each state and year between 1989 and 2013. The laws govern small-group fully-insured health plans, which are plans covered by a commercial insurance company. ${ }^{14}$ The small-group market generally applies to employers with 50 or fewer employees but may be restricted to groups with 25 employees or fewer, depending on state law.

The state rate-restriction data was collected from state legislative histories, legal databases, communication with state insurance departments, academic articles, and other sources. We used annual data published by other organizations that documented state policies in individual years to cross-reference the data that we collected. ${ }^{15}$ But, for most years in our sample period, the data were not available through previously published sources.

The variable of interest is a state's rate bands, which proscribes the maximum ratio of premiums for firms with unhealthy policyholders relative to firms with healthy policyholders. Some states also set a maximum ratio of premiums based on the average age of the firm's employees, as the ACA does (at 3:1) from 2014 onward, but these bands are rarer, and records of the actual proscribed ratio is less complete. Only one state prohibited rate differences by age immediately before the ACA made it illegal nationwide: New York, as part of adopting pure community rating in 1993 (Adams 2007). Regardless, older workers, who are generally less healthy than younger workers, stand to gain more from restrictions on unhealthy workers' premiums.

In addition to documenting whether or not states have active rate band laws (i.e., the extensive margin), we track the rate-band ratios permitted under state law (i.e., the intensive margin). A rate-band ratio of 1 (1:1) is the most restrictive policy, as the maximum premium is the same as the minimum; a rate-band ratio of 1 occurs in states with pure or modified community rating, because by definition premiums do not vary by the health composition of a firm's employees. A rate-band ratio of 0 indicates that the state has no rate band law, and is therefore the least restrictive. Yet a rate-band ratio of 4:1, although larger in value, is less

\footnotetext{
${ }^{14}$ Self-insured health plans, in which the employer assumes the cost and risk of covering medical claims, are governed by federal legislation and are not the focus of this study. Between 1996 and 2011, approximately 12 percent of employers with fewer than 50 employees opted to self-insure (EBRI 2012).

${ }^{15}$ These sources include NAIC (2000; 2012), the Health Policy Tracking Service (1996-2000), Kaminsky (2008), Politico (2009), Kofman and Pollitz (2006), GAO (1992; 1995), Markus et al. (1995), National Women’s Law Center (2008), and Kaiser (2013).
} 
restrictive than a ratio of 2:1. Rather than using a measure that is non-monotonic in the strength of the restriction, our key variable is this ratio’s inverse. Instead of a 4:1 ratio, we use its inverse, or 0.25 (a 2:1 ratio's inverse is 0.5 etc.), so that a larger value reflects a more restrictive law. Taking the inverse of the ratio also constrains it within the $[0,1]$ range.

For most states, we were able to document when a rate band was adopted, but often the specific ratio could not be identified. In this instance, the ratio itself is marked as missing (and therefore not part of the regression sample), but the state and year is flagged as having a rate band. In other instances, we were able to identify a year that a state had a particular rate-band ratio, as well as a year it did not have that ratio, but the exact year in which the law itself was passed is unknown. For these states, we randomized the year between the two known dates to approximate the date it was enacted.

Table 1 lays out the timeline for when small-group premium restrictions were implemented. In 1989, no state restricted small-group health insurance premiums, but by 1991, 17 states had adopted some level of restriction, including two states that prohibited any premium variation by health (Massachusetts and Vermont). By 1995, 46 out of the 50 states analyzed (Hawaii is excluded and Washington, D.C. is included) had adopted some restriction; at that point, the average ratio of highest to lowest premiums was 1.56:1. Thereafter, though some states changed their ratios, the national average ratio stayed fairly constant. In 2013, every state had some premium restriction in the small group market, but we categorize 16 of them as “weak” - ratios between 1.86:1 and 4:1 - and the national average ratio was just over 1.5:1. ${ }^{16}$

The regression analysis uses the rate band as the key independent variable and focuses on three outcome variables. For the first outcome, an indicator for employment, we estimate a linear regression for individual $i$ living in state $s$ in year $t$ :

$$
\begin{gathered}
Y_{i s t}=\alpha_{0}+\alpha_{1} \text { Band }_{s t}+\alpha_{2} \text { Ratio }_{s t}+\alpha_{3} \text { Age } 50_{i t}+\alpha_{23} \text { Ratio }_{s t} \text { Age } 50_{i t} \\
+\gamma X_{i t}+\psi_{s}+\tau_{t}+\varepsilon_{i s t}
\end{gathered}
$$

\footnotetext{
${ }^{16}$ A ratio of $1.86: 1$ is a rating restriction where the maximum premium variation is 30 percent above or below the average - hence, a 1.3/0.7 ratio, or 1.86 .
} 
Band $_{s t}$ is an indicator equal to one if state $s$ has any rate band in year $t$. Ratio $s t$ is the maximum allowable ratio of the premiums at firms with healthy enrollees to the premiums at firms with unhealthy enrollees (and zero if the state lacks a rate band); a ratio closer to 1 implies a stronger restriction. The variables are controlled for separately to allow states that had made the decision to establish a weak rate band (i.e., with Ratio $_{s t}$ close to zero), thereby permitting great variation in premiums by health, to differ from states that have not yet established a definitive policy on premium variation.

$A g e 50_{i t}$, an indicator equal to one if individual $i$ is ages 50-61, is interacted with Ratio $_{\text {st }}$. Conceptually, older workers benefit more from restrictions on the cost of hiring unhealthy workers, so $\alpha_{23}$ is predicted to be positive and statistically significant. Younger workers might also benefit if they have health limitations, so the sign and significance of $\alpha_{2}$ is ambiguous.

Equation (1) also includes a vector of personal characteristics, $X_{i t}$ : categorical variables for education and race; indicators for Hispanic ethnicity, marital status, and gender; and continuous variables for household income and the average state unemployment rate over year $t$.

Most specifications of the model also include state fixed effects, $\psi_{s}$, to capture timeinvariant differences in states that adopted premium restrictions early or late. We report the earnings results separately with and without state fixed effects, because the average earnings states with strong premium restrictions differed substantially from earnings in states with weak premium restrictions. We do not report separate results without and with state fixed effects in the employment regressions, because in the difference in employment rates between strong and weak states was small. The model also includes year fixed effects, $\tau_{t}$, to capture nationwide fluctuations in employment or earnings.

The second outcome variable reflects that the regulations were targeted at workers at small firms; the workers at larger firms would be affected only indirectly, e.g., by changes in labor supply (individuals may be more likely to work if small firms’ offers are more competitive). One issue with using small firm employment as the outcome variable is that the alternative is not clear: is the comparison group only workers at large firms, or is it both workers at large firms and the non-employed? To account for each alternative, we estimate two different models. 
The first approach estimates a multinomial logit regression to reflect the idea that workers may choose large employers, small employers, or non-employment. ${ }^{17}$ The $Y_{\text {ist }}$ variable in this case is a categorical variable with small-firm employment and non-employment as separate options; employment at a large firm is the reference condition. Small-firm employment is defined as working for an employer with fewer than 100 employees. Although most smallgroup rate restriction laws apply to employers with 50 employees or fewer, the firm-size variable in the CPS is not structured in a way that allows us to identify that subgroup without losing observations. ${ }^{18}$ Due to the non-linearity of the multinomial logit model, we report marginal effects (i.e., mean derivatives of $Y_{i s t}$ with respect to each variable) and their standard errors; interaction effects also account for this non-linearity (Ai and Norton 2003).

The second approach estimates a model identical to equation (1), except that the dependent variable is $S_{m a l l}$, an indicator for working at a small firm at time $t$. In this approach, the sample is limited to the employed; the only alternative to small-firm employment in this model is working at a large firm.

In either approach, small-firm employment should increase more than large-firm employment when the rate-band ratio is stronger $\left(\alpha_{2}>0\right)$, and this effect should be especially large for older workers $\left(\alpha_{23}>0\right)$.

The third outcome variable is log real annual earnings; if premium restrictions make older workers more attractive to employers, their wage offers should rise. The model is similar to equation (1), except that it is supplemented with further interactions with the indicator for small-firm employment, Small $_{i t}$ :

$$
\begin{aligned}
Y_{i s t}=\beta_{0}+\beta_{1} \text { Band }_{s t}+\beta_{2} \text { Ratio }_{s t}+\beta_{3}{\text { Age } 50_{i t}}_{i t} \beta_{4} \text { Small }_{i t} \\
+\beta_{23} \text { Ratio }_{s t}{\text { Age } 50_{i t}+\beta_{24} \text { Ratio }_{s t} \text { Small }_{i t}} \\
+\beta_{234} \text { Ratio }_{s t} \text { Small }_{i t} \text { Age } 50_{i t}+\gamma X_{i t}+\psi_{s}+\tau_{t}+\varepsilon_{i s t}
\end{aligned}
$$

\footnotetext{
${ }^{17}$ We use multinomial logit rather than ordered logit because we do not assume that one firm size category is universally preferred to another. Kapur (2003) also uses multinomial logit for her main specification.

18 The CPS ASEC grouped together all firms with 10 to 24 employees, and another category with 25 to 99 employees until March 2010. Starting in March 2011, these groups were reassigned: 10 to 49 employees in one category, 50 to 99 in another. Therefore, the only time-consistent firm size definition for the 1989-2013 period groups together all employers with 99 or fewer employees.
} 
Conceptually, $\beta_{24}$ should be statistically significant and positive - all workers (regardless of age) in small firms should benefit from higher wage offers by virtue of being less expensive to their employers. Also, because rate bands affect only the small group health insurance market, $\beta_{2}$ should be statistically indistinct from zero; otherwise, the estimate suggests a spillover effect onto large firms. Most importantly, the coefficient on the triple interaction of Ratio ${ }_{s t}$, Small $_{i t}$, and $A g e 50_{i t}, \beta_{234}$, is expected to be positive and statistically significant, as older workers in small firms are particularly likely to benefit from strong premium restrictions.

Additional specifications include an indicator variable for bad health and its interaction with Ratio $_{s t}$; in some specifications, the bad health indicator replaces $A g e 50_{i t}$, and in others, both are included with a triple interaction of bad health, $A g e 50_{i t}$, and Ratio $o_{s t}$. The earnings regressions in the robustness check section also include a quadruple interaction between fair or poor health, Ratio ${ }_{s t}, S_{m a l l}$, and $A g e 50_{i t}$, to determine whether workers at small firms who are both older and less healthy earn more when the rate-band ratio is more restrictive. Bad health is defined as reporting fair or poor health on a five-point scale. ${ }^{19}$ Unfortunately, these questions were added to the ASEC only in March 1996, so specifications that include this variable (and its interactions) are limited to 1995-2013; this period restriction eliminates the years when most of the rate bands were being introduced. Unhealthy workers are expected to benefit most from strong premium restrictions, especially if they work in small firms and/or are 50 or older. But employers that fear the cost of compliance with premium restrictions may subtly discriminate against potentially unhealthy workers, which would lower their probability of being employed and their earnings; some researchers find a similar phenomenon after the Americans with Disabilities Act, for example. ${ }^{20}$

\section{Results}

Descriptive Statistics. Table 2 provides means for each variable for the full sample and for residents of states with varying degrees of premium restriction: none, weak, strong, or community rating (i.e., prohibitions on premium differences due to employee health, though not necessarily pure community rating). About half of the CPS sample is covered by employer-

\footnotetext{
${ }^{19}$ Results are similar when bad health's definition includes work limitations.

${ }^{20}$ For example, see DeLeire (2000) and Acemoglu and Angrist (2001), though subsequent researchers have found positive effects of the ADA and similar legislation on employment of the impaired (Kruse and Schur 2003; Jolls and Prescott 2004; Button 2016).
} 
sponsored health insurance, and that proportion is roughly constant regardless of the level of premium restriction. Approximately 26 percent of the sample is 50 or older; the share over age 50 , as well as the average ages, are similar in each of the three groups of states with premium restrictions, but the states with no restrictions are somewhat younger, likely because those observations are from an earlier time period when the Baby Boomers were still fairly young.

The states that adopted community rating are better educated -34 percent of all sample members from community rating states have college degrees, versus 26 percent in states with no rating restriction. This difference is even greater at older ages (34 percent in restricted states versus 22 percent in unrestricted states). The healthiest residents are in states that adopted community rating, with a more pronounced difference among older individuals. Community rating states also have higher household incomes and earnings, including earnings at a small firm. The differences in health, education, and income between states with strong (excluding community rating) and weak restrictions are quite small, however. Gender and marital status are almost exactly equal across all restriction categories, but strong and community rating states are more diverse, in particular in their shares of residents with Asian or Hispanic heritage.

The final section of Table 2 displays the differences in employment variables, an outcome of interest. Overall employment is similar across states, regardless of the rate band category, but small-firm employment is somewhat higher in states with strong restrictions or community rating. Similarly, full-time employment is constant across premium restriction categories but is modestly higher in states in the strong or community rating categories. The descriptive statistics imply that states that adopted varying degrees of premium restrictions differ in some key characteristics. These differences motivate the regression analysis.

Overall Employment. Table 3 reports the results of linear regressions for total employment and for small-firm employment only. Each model includes state fixed effects to capture unobservable but time-consistent differences across states that adopted stronger or weaker premium restrictions. Results without state fixed effects are similar, because the correlation between employment rate and rate-band ratio is very small (a correlation coefficient of 0.07); these results are available upon request.

The first column of Table 3 presents estimates using employment as the dependent variable. States with a rate band have a 1-percentage-point lower employment rate. Given that 
the mean employment rate is 77 percent of the state's population, this estimate is a small number, albeit precisely estimated. The magnitude of the ratio does not appear to affect employment at younger ages - the point estimate for the ratio without interactions is small and statistically insignificant. However, among older workers, the interaction effect indicates that employment is statistically significantly more likely, though by only about 3 percentage points (on a mean of 70 percent) when a state moves from the equivalent of no rate band (ratio of zero) to community rating (ratio of one). ${ }^{21}$

Small-Firm Employment. The results in the first column of Table 3 indicate that employment increases by a small amount for older workers employed by firms with 100 or fewer employees. Conceptually, the small-group premium restrictions should primarily affect smallfirm employment, while large firms, and their employees, would be affected by the restrictions only indirectly, through changes in the relative attractiveness of large-firm employment or through spillovers to their health insurance premiums.

The middle panel of Table 3 presents the multinomial logit estimates, where the base outcome in each case is large-firm employment. The estimates do not indicate a larger increase in small-firm employment than in large-firm employment when state premium restrictions are strengthened. ${ }^{22}$ The results are similar in a simpler one-equation model where small-firm employment is the dependent variable (rightmost column of Table 3) and large firms are the comparison group (the sample is limited to the employed). This simpler model also indicates that small firm employment is not statistically significantly different in states with strong premium regulations. There also is no difference in small firm employment of older and primeage workers depending on the strength of the regulations.

Figure 1 summarizes the results for employment in small and large firms by rate band strength. The full height of each bar is the predicted probability of being employed (irrespective of firm size) when every variable other than rate-band ratio and either age and/or health are at the sample mean. The height of the red area represents the predicted probability of working in a

\footnotetext{
${ }^{21}$ More accurately, the model projects that moving from no rate band to community rating would increase employment by only 2 percentage points: 3 percentage points from the interaction of rate-band ratio and age-50plus, plus essentially zero from the ratio coefficient itself, minus 1 percentage point for the rate band indicator.

22 The estimates in the unemployed equation of the multinomial logit model are consistent with the overall employment results: older workers are less likely to be non-employed when premiums are more restricted.
} 
small firm. The height of the gray area in the bar is the predicted probability of working in a large firm. The results are based on the multinomial logit estimates in the middle panel of Table 3.

Figure 1 makes clear that premium restrictions do not increase employment in small firms - or employment overall. The left panel of Figure 1 indicates that the predicted employment rate for older individuals barely increases as the strength of the premium restrictions increases: from 69 percent with no rate band to 72 percent with community rating. Small-firm employment among individuals 50 and older increases by even less. Prime-age individuals also do not see an increase in small-firm employment or overall employment.

In summary, states that have enacted stronger premium restrictions are associated with only slightly higher overall employment for older individuals, and no increase in small-firm employment. This group should be most likely to benefit from regulation aimed at limiting the negative effect of hiring or retaining workers with higher health costs, but the reforms did not appear to help improve older workers' prospects of being employed at the firms most concerned about how expensive these workers are to insure.

Earnings. Unlike employment, the results of the earnings regressions in Table 4 indicate that workers are paid more in states with stronger premium restrictions. Workers of all ages at small firms generally earn less, as seen in the coefficient of -0.34 for small firms (without interactions). The negative coefficient, -0.07 , on the rate band ratio (without interactions) indicates that earnings fall at large firms as the premium regulations strengthen. But the coefficient on the small-firm interaction with the rate-band ratio is virtually the same magnitude as the coefficient on the ratio without an interaction, but of opposite signs, suggesting that the earnings of workers at small firms are essentially unchanged by the premium restrictions. This result - a decrease in earnings at larger firms, but no change at small firms - means that as premium regulations grow stronger, earnings for workers at small firms close the difference with large-firm workers by a statistically significant margin. Furthermore, older workers at small firms see a slightly larger increase in earnings as restrictions tighten, but that boost is not statistically significant (as seen in the triple-interaction coefficient).

Figure 2 shows how the earnings gap between large and small firms falls as premium regulations strengthen (using the fixed effects results from column 2 of Table 6). Workers at 
large firms earn more across the board, but their advantage shrinks as the restrictions tighten, and it decreases at a slightly faster rate for older workers. The gap between large- and small-firm earnings for older workers is $\$ 13,400$ with no premium restriction and falls to $\$ 9,980$ with community rating - that $\$ 3,420$ decrease is 26 percent of the gap for no premium restriction. The gap for prime-age workers falls from $\$ 10,670$ to $\$ 8,150$, a decrease of just $\$ 2,520$ but still a 23 percent change due to the smaller earnings gap for younger workers.

The estimates in Table 4 are presented both without and with state fixed effects to show how the results are altered by accounting for the time-invariant unobservable differences across states that implemented varying levels of restriction in premium. The correlation between a state's average earnings and its rate-band ratio is 0.32 , and 0.39 excluding states without any rate band - both of which are much stronger than the correlation between employment and the ratio.

The importance of controlling for the non-random rollout of rate bands is also evident in Table 4. The estimates without state fixed effects (column 1) imply a check-mark shape: residents of states with no rate band have fairly high earnings, as do those in states with community rating (where the ratio equals one), and earnings are lowest for states with very weak regulations. When state fixed effects are added, however, the rate band indicator's coefficient flips signs - rate bands are associated with lower earnings - but estimate is statistically insignificant and smaller. The fact that the sign flips when we add fixed effects reinforces the pattern from Table 2: earnings are lowest in states that implemented rate bands, but only weak versions of them. The other estimates are almost exactly the same, however, which suggests that the states that passed stricter regulations had greater earnings overall and not just among workers in a particular age or health group.

In summary, in states with stricter premium restrictions, earnings are lower for prime-age workers in large firms, a group that was expected to be unaffected by the regulations; these results contrast with the employment analysis, which saw no change for employees at large firms. For all workers, the gap in earnings between large- and small-firm employees shrinks appropriately, for a regulation that reduced the difference in health care costs among firms. The gap shrank even more for older workers who would have raised small firms' premiums the most, though not by a statistically significant margin. The premium regulations also modestly improved the earnings of its intended beneficiaries - older workers at small firms - by more than prime-age workers. 
Results by Socioeconomic Status. The results in Table 5 indicate that the socioeconomic group most likely to benefit from stricter premium regulations was high school graduates without any college experience. They saw both overall employment increases and a shrinking gap in earnings between large and small firms. Importantly, however, no group saw employment growth at small firms.

The older workers who benefit most consistently from premium restrictions are high school graduates, who see increases both in their earnings at small firms (relative to workers in large firms) and in their overall employment. Individuals with some college experience also see increasing earnings and overall employment - though of lesser, statistically insignificant magnitudes - under stronger premium restrictions. High school dropouts see no statistically significant increase in overall employment, and earnings at small firms actually fall relative to large firms. ${ }^{23}$ College graduates see overall employment increases with stricter regulation, but no statistically significant change in the earnings gap.

Because premium restrictions are most likely to affect workers who are offered health benefits - generally full-time workers - we estimate separate results (available upon request) where the dependent variable is either full-time employment (relative to part-time employment) or small-firm full-time employment (relative to all other employment). For the full sample and the groups with at least a high school degree, a stronger rate-band ratio is associated with a statistically significant increase in employment, relative to prime-age workers. Older high school dropouts, however, have statistically significantly lower full-time employment, and fulltime employment at small firms, in states with stricter rate bands.

Results Using Fair or Poor Health. Insurers view older workers as bad risks - not because they are old, but because they are more likely to be in poor health. But clearly not all workers age 50-61 are unhealthy, and unhealthy workers of all ages benefit from premium restrictions. Appendix Tables A1-A3 report results where the age-50-plus indicator is either replaced by an indicator for fair or poor health, or interacted with the fair or poor health

\footnotetext{
${ }^{23}$ The model predicts that earnings at small firms are 5.9 percent lower for older workers without a high school degree in states with (pure or modified) community rating compared to states with no rate restrictions. That decrease is mostly due to the interaction between the rate band ratio and the indicator for age 50 plus (fourth row). The estimated effect on small-firm earnings is positive for the other three education categories because that interaction is positive or only barely negative.
} 
indicator. In addition, because health is available only in the 1995-2013 period, each table's first column re-estimates the age-50-plus regression for this shorter period.

The estimated coefficients and interaction effects involving health exhibit patterns similar to the age-50-plus regressions: no substantial increase in overall or small-firm employment as the ratio increases. The one exception is the earnings regressions: the earnings gap between large and small firms shrinks by less as the ratio increases. The smaller change in the 1995-2013 period may be due to the fact that, by 1995, 46 states had already adopted some form of premium restrictions. Fewer regulatory changes in this relatively short time frame make earnings changes smaller and harder to detect. Finally, in all specifications, the interaction of the rate-band ratio, fair or poor health, and age-50-plus is not statistically significant, which implies that workers who are both older and unhealthy do not have appreciably worse outcomes than workers who are either old or unhealthy.

\section{Conclusions}

The labor supply of older workers is increasing, but whether demand for these older workers will persist remains a concern, because older workers cannot work longer if jobs are not available to them. While some proposed policies to increase the attractiveness of older workers remain abstract, one policy adopted by many states has had the potential to improve labor market outcomes at older ages. This study examines that policy - tighter regulation of health insurance

premiums for less healthy (typically older) workers in the small-group market - to determine the extent to which the policy increased older workers' employment and earnings overall, particularly in the small firms most sensitive to the regulations. The study further compares how this policy affected better- and less-educated workers.

The results indicate that stronger premium restrictions are associated with only slightly higher overall employment for older individuals and no detectable increase in the probability of working at a small firm. In states with stronger regulations, total employment increases at a modest rate for older workers with a high school degree or more but declines for older workers (relative to prime-age workers) with less than a high school degree. And no education group sees the expected increase in small-firm employment.

Earnings show a clearer benefit from stronger small-group premium regulations. Workers at small firms close a substantial amount of their earnings gap with workers at large 
firms when premium regulations tighten. Less-educated workers see this earnings gap close the most. The gap closes somewhat more for older workers, but not by a statistically significant amount.

These results suggest that small-group health insurance premium regulation have only a limited effect on the attractiveness of older workers to potential employers. Older workers' likelihood of being employed is unaffected, but those who are employed do benefit from more competitive wage offers.

This study took advantage of an opportunity that has now disappeared: using differences across states in small-group premium regulation to examine how the price of hiring an extra older worker affected labor market outcomes. The ACA's nationwide rollout spelled the end of this state-by-state variation, so other strategies will be needed in the future to examine how attempts to increase the financial attractiveness of older workers might improve their prospects for working longer. The results for the period when that state variation did exist, however, indicate that older workers at small firms - particularly the less-educated - may benefit from higher earnings, but that older workers are not likely to see an increase in employment. Therefore, an indirect approach to reducing the price of hiring an additional older worker restrictions on insurance premiums - does not appear to help. To improve their labor market conditions, policymakers may have to increase their attractiveness more directly, perhaps by subsidizing the hiring of older workers. 


\section{References}

Acemoglu, Daron and Joshua D. Angrist. 2001. "Consequences of Employment Protection? The Case of the Americans with Disabilities Act.” Journal of Political Economy 109(5): 915957.

Adams, Scott. 2007. "Health Insurance Market Reform and Employee Compensation: The Case of Pure Community Rating in New York.” Journal of Public Economics 91: 1119-1133.

Agency for Healthcare Research and Quality. Medical Expenditure Panel Survey- Insurance Component, 1996-2013. Rockville, MD.

Ai, Chunrong and Edward C. Norton. 2003. "Interaction Terms in Logit and Probit Models.” Economic Letters 80(1): 123-129.

Autor, David H. 2014. “Polanyi’s Paradox and the Shape of Employment Growth.” Working Paper 20485. Cambridge, MA: National Bureau of Economic Research.

Baicker, Katherine and M. Marit Rehavi. 2004. "Policy Watch: Trade Adjustment Assistance.” The Journal of Economic Perspectives 18(2): 239-255.

Baker, Robin. 2007. "Rate Regulation in the Small-Group Health Insurance Market.” Denver, CO: The Bell Policy Center:

Blinder, Alan S. 2010. "Getting the Biggest Bang for Job-Creation Bucks.” (February 19). The Washington Post. Washington, DC. Available at: http://www.washingtonpost.com/wpdyn/content/article/2010/02/18/AR2010021802607.html.

Boockmann, Bernhard, Thomas Zwick, Andreas Ammermüller, and Michael Maier. 2007. “Do Hiring Subsidies Reduce Unemployment Among the Elderly? Evidence from Two Natural Experiments.” Discussion Paper 07-001. Mannheim, Germany: Centre for European Economic Research (ZEW).

Bound, John, Arline Geronimus, Javier Rodriguez, and Timothy Waidmann. 2014. "The Implications of Differential Trends in Mortality for Social Security Policy.” Working Paper 2014-314. Ann Arbor, MI: Michigan Retirement Research Center.

Buchmueller, Thomas, and John DiNardo. 2002. "Did Community Rating Induce an Adverse Selection Death Spiral? Evidence from New York, Pennsylvania, and Connecticut.” The American Economic Review 92(1): 280-294.

Burtless, Gary and Joseph Quinn. 2002. “Is Working Longer the Answer for An Aging Workforce?” Issue in Brief 11. Chestnut Hill, MA: Center for Retirement Research at Boston College. 
Button, Patrick. 2016. "Expanding Employment Discrimination Protections for Individuals with Disabilities: Evidence from California.” Working Paper No. 1601. New Orleans, LA: Tulane University.

California Health Care Foundation. 2003. “Insurance Markets: Rules Governing California’s Small Group Health Insurance Market.” Oakland, CA.

Centers for Medicare \& Medicaid Services (CMS). 2013. “Overview: Final Rule for Health Insurance Market Reforms.” Baltimore, MD.

Chaikind, Hinda R., Jean Hearne, Bob Lyke, and Stephen Redhead. 2005. “The Health Insurance Portability and Accountability Act (HIPAA) of 1996: Overview and Guidance on Frequently Asked Questions.” Washington, DC: Congressional Research Service.

DeLeire, Thomas. 2000. "The Wage and Employment Effects of the Americans with Disabilities Act.” Journal of Human Resources 35(4): 693-715.

Delong, J. Bradford. 2010. “Economists for Wage Subsidies.” Blog post. Available at: http://delong.typepad.com/sdj/2010/02/economists-for-wage-subsidies.html.

Employee Benefit Research Institute. 2005. "Fundamentals of Employee Benefit Programs, Part Three: Health Benefits.” Washington, DC.

Eppel, Rainer and Helmut Mahringer. 2012. Do Wage Subsidies Work in Boosting Economic Inclusion? Evidence on Effect Heterogeneity in Austria.” Working Paper. Vienna, Austria: Austrian Institute of Economic Research (WIFO).

Flood, Sarah, Miriam King, Steven Ruggles, and J. Robert Warren. Integrated Public Use Microdata Series, Current Population Survey: Version 4.0, 1990-2014. Minneapolis, MN: University of Minnesota.

Fronstin, Paul. 2012. "Self-Insured Health Plans: State Variation and Recent Trends by Firm Size.” Note 33(11). Washington, DC: Employee Benefit Research Institute.

Garcia-Perez, J. Ignacio and Yolanda Rebollo Sanz. 2009. "Do Wage Subsidies Affect the Subsequent Employment Stability of Permanent Workers?: The Case of Spain.” Working Paper Econ 9.18. Seville, Spain: Universidad Pablo de Olivide.

Glaeser, Edward. 2013. “A Better Way to Help the Working Poor.” (February 19). Bloomberg View. New York, NY. Available at: http://www.bloomberg.com/view/articles/2013-0220/use-tax-credit-not-minimum-wage-to-help-poor.

Glied, Sherry and Mark Stabile. 2001. “Avoiding Health Insurance Crowd-Out: Evidence from the Medicare as Secondary Payer Legislation.” Journal of Health Economics 20: 239260. 
Goda, Gopi Shah, John B. Shoven, and Sita Nataraj Slavov. 2007. "A Tax on Work for the Elderly: Medicare as Second Payer.” Working Paper 13383. Cambridge, MA: National Bureau of Economic Research.

Goda, Gopi Shah, John B. Shoven, and Sita Nataraj Slavov. 2009. "Removing the Disincentives in Social Security for Long Careers.” In Social Security Policy in a Changing Environment, edited by Jeffrey Brown, Jeffrey Liebman and David A. Wise, 21-38. Cambridge, MA: National Bureau of Economic Research.

Health Policy Tracking Service. 1996. "Major Health Care Policies: 50 State Profiles, 1996.” Washington, DC.

—. 1997. "Major Health Care Policies: 50 State Profiles, 1997.” Washington, DC.

—. 1998. "Major Health Care Policies: 50 State Profiles, 1998.” Washington, DC.

—_ 1999. "Major Health Care Policies: 50 State Profiles, 1999.” Washington, DC.

—_. 2001. "Major Health Care Policies: 50 State Profiles, 2001.” Washington, DC.

Heaton, Paul. 2012. "The Effects of Hiring Tax Credits on Employment of Disabled Veterans." Occasional Paper 366. Santa Monica, CA: RAND.

The Henry J. Kaiser Family Foundation. 2013. "Small Group Health Insurance Market Rate Restrictions.” Washington, DC.

Hirsch, Jeffrey M., Paul M. Secunda, and Richard A. Bales. 2013. "Understanding Employment Law” 2nd Ed. LexisNexis Group.

Huttunen, Kristiina,, Jukka Pirttilä, and Roope Uusitalo. 2010. “The Employment Effects of Low-Wage Subsidies.” Discussion Paper 4931. Bonn, Germany: Institute for the Study of Labor (IZA).

Johnson, Richard W. 2003. "Changing the Age of Medicare Eligibility: Implications for Older Adults, Employers, and the Government.” Washington, DC: Urban Institute.

Jolls, Christine and J.J. Prescott. 2004. "Disaggregating Employment Protection: The Case of Disability Discrimination.” Working Paper 10740. Cambridge, MA: National Bureau of Economic Research.

Kaestner, Robert and Kosali Ilayperuma Simon. 2002. "Labor Market Consequences of State Health Insurance Regulation.” Industrial and Labor Relations Review 56(1): 136-159.

Kapur, Kanika. 2003. "Labor Market Implications of State Small Group Health Insurance Reform.” Public Finance Review 31(6): 571-600. 
Kapur, Kanika. 2004. “The Impact of the Health Insurance Market on Small Firm Employment.” Journal of Risk and Insurance 71(1): 63-90.

Kaminski Leduc, Janet L. 2008. “Community versus Experience Rating Health Insurance.” Hartford, CT: State of Connecticut General Assembly.

Klein, Karen E. 2010. “Don’t Overlook the Jobs Bill’s Tax Incentives.” (May 25). Bloomberg Businessweek. Available at: http://www.businessweek.com/smallbiz/content/may2010/sb20100524_004899.htm.

Kofman, Mila and Karen Pollitz. 2006. "Health Insurance Regulation by States and the Federal Government: A Review of Current Approaches and Proposals for Change.” Washington, DC: Georgetown University Health Policy Institute.

Koller, Christopher F. 2006. “Small Group Health Insurance Reform in New Hampshire.” Cranston, RI: State of Rhode Island Office of the Health Insurance Commissioner.

Kruse, Douglas and Lisa Schur. 2003. "Employment of People with Disabilities Following the ADA.” Industrial Relations 42(1): 31-64.

Lo Sasso, Anthony T. and Ithai Z. Lurie. 2009. "Community Rating and the Market for Private Non-Group Health Insurance.” Journal of Public Economics 93: 264-279.

Markus, Anne R., Kala Ladenheim, and Lisa Atchison. 1995. "Small Group Market Reforms: A Snapshot of States' Experience.” Washington, DC: The Commonwealth Fund/Intergovernmental Health Policy Project at Georgetown University.

Monheit, Alan C. and Barbara Steinberg Schone. 2003. "How Has Small Group Market Reform Affected Employee Health Insurance Coverage?” Journal of Public Economics 88: 237254.

Munnell, Alicia H. and Matthew S. Rutledge. 2013. "The Effects of the Great Recession on the Retirement Security of Older Workers." Annals of the American Academy of Political and Social Science 650: 124-142.

National Association of Insurance Commissioners. 2000. "NAIC Compendium of State Laws on Insurance Topics: Small Group Health Insurance Availability.” Washington, DC.

— 2012. "NAIC Compendium of State Laws on Insurance Topics: Small Group Health Insurance Availability.” Washington, DC.

National Women’s Law Center. 2008. “Women and Employer-Sponsored Insurance.” Washington, DC.

Neumark, David and Joanne Song. 2013. "Do Stronger Age Discrimination Laws Make Social Security Reforms More Effective? Journal of Public Economics 108(C): 1-16. 
Ondrasik, Paul J. and Eric G. Serron. 2008. "ERISA Preemption and State Health Care Reform (Part 1).” Infrastructure 47(3): 1-5.

Pethokoukis, James. 2013. “Subsidize Business for Pay Raises.” (December 4). The New York Times. New York, NY. Available at: http://www.nytimes.com/roomfordebate/2013/12/04/making-low-wagesliveable/subsidize-business-for-pay-raises.

Pierron, William and Paul Fronstin. 2008. "ERISA Pre-emption: Implications for Health Reform and Coverage.” Issue Brief No. 314. Washington, DC: Employee Benefit Research Institute.

Politico. 2009. “Health Care Reform Premium Impact in Missouri.” Arlington, VA.

Pollitz, Karen, Nicole Tapay, Elizabeth Hadley, and Jalena Specht. 2000. "Early Experience with ‘New Federalism’ in Health Insurance Regulation.” Health Affairs 19(4): 7-22.

Rosenbaum, Sara. 2009. "Insurance Discrimination on the Basis of Health Status: An Overview of Discrimination Practices, Federal Law, and Federal Reform Options.” Washington, DC: The Linda D. and Timothy J. O’Neill Institute for National and Global Health Law at Georgetown Law.

Rovner, Jack A. 1998. “Federal Regulation Comes to Private Health Care Financing: The Group Health Insurance Provisions of the Health Insurance Portability and Accountability Act of 1996.” Annals of Health Law 7(1): 183-215.

Ruegger, Durwood. 1989. “A Twenty-Year History and Review of the ADEA.” Labor Law Journal 40(1).

Sanzenbacher, Geoffrey T., Anthony Webb, Candace M. Cosgrove, and Natalia S. Orlova. 2015. “Calculating Neutral Increases in Retirement Age by Socioeconomic Status.” Working Paper 2015-22. Chestnut Hill, MA: Center for Retirement Research at Boston College.

Schunemann, Benjamin, Michael Lechner, and Conny Wunsch. 2011. "Do Long-term Unemployed Workers Benefit from Targeted Wage Subsidies.” Discussion Paper 201126. St. Gallen, Switzerland: University of St. Gallen.

Simon, Kosali Ilayperuma. 2005. “Adverse Selection in Health Insurance Markets? Evidence from State Small-group Health Insurance Reforms.” Journal of Public Economics 89: 1865-1877.

State of Florida Committee on Banking and Insurance. 1999. "Report Number 2000-04: Review of Florida's Health Insurance Laws Relating to Rate and Access to Coverage.” Tallahassee, FL. 
State of Hawaii Department of Labor and Industrial Relations: Disability Compensation Division. 2013. "Highlights of the Hawaii Prepaid Health Care Law.” Honolulu, HI.

Taylor, Philip. 2002. New Policies for Older Workers. Bristol, UK: The Policy Press.

U.S. Department of Health and Human Services: Office of the Assistant Secretary for Planning and Evaluation. 2000. "The Impact of Access Regulation on Health Insurance Market Structure.” Washington, DC.

U.S. Equal Opportunity Commission. 2000. "EEOC Compliance Manual, Chapter 3: Employee Benefits.” Washington, DC.

U.S. General Accounting Office. 1992. “Access to Health Insurance: State Efforts to Assist Small Businesses.” Washington, DC.

— . 1995. "Health Insurance Regulation: Variation in Recent State Small Employer Health Insurance Reforms.” Washington, DC.

— 1999. "Private Health Insurance: Impact of Premium Increases on Number of Covered Individuals Is Uncertain.” Washington, DC.

Wicks, Elliot K. 2005. "Premium Variation in the Small-Group Market in Delaware: Analysis of the Problem and Possible Solutions.” Economic and Social Research Institute/Health Management Associates. 
Table 1. Distribution of State Rate Restriction Policies, 1989-2013

\begin{tabular}{lrrrrr}
\hline & 1989 & 1991 & 1995 & 2000 & 2013 \\
\hline Community rating & & & & & \\
$\quad$ \% sample & $0.0 \%$ & $4.8 \%$ & $28.1 \%$ & $23.5 \%$ & $25.2 \%$ \\
$\quad$ No. states & 0 & 2 & 13 & 11 & 12 \\
Strong & & & & & \\
$\quad$ \% sample & 0.0 & 19.6 & 50.7 & 50.9 & 50.1 \\
$\quad$ No. states & 0 & 13 & 26 & 25 & 20 \\
Weak & & & & & \\
$\quad$ \% sample & 0.0 & 5.5 & 11.4 & 18.2 & 24.7 \\
$\quad 0$ & 2 & 7 & 11 & 16 \\
$\quad$ No. states & & & & & \\
None & 100.0 & 70.2 & 9.8 & 7.5 & 0.0 \\
$\quad$ \% sample & 50 & 30 & 4 & 3 & 0 \\
$\quad$ No. states & 50 & 47 & 50 & 50 & 48 \\
\hline Total states with known ratio & ---- & 4.35 & 1.56 & 1.57 & 1.51 \\
Avg. ratio & & & & & \\
\hline
\end{tabular}

Note: Totals exclude HI and includes DC. 1991 rate band data is missing for CO, CT, and OR, while 2013 rate band data is missing for DC and PA. "Community rating" refers to a 1:1 rate-band ratio, "Strong" includes ratios between 1.2:1 and 1.67:1, and "Weak" includes ratios between 1.86:1 and 4:1.

Source: Authors' calculations from the Current Population Survey (CPS). 
Table 2. Descriptive Statistics for Full and Rate Band Subsamples

\begin{tabular}{|c|c|c|c|c|c|}
\hline & Full sample & None & Weak & Strong & $\mathrm{CR}$ \\
\hline \multicolumn{6}{|l|}{ Race } \\
\hline White & 83\% & $84 \%$ & $85 \%$ & $81 \%$ & $83 \%$ \\
\hline Black & 11 & 12 & 9 & 11 & 10 \\
\hline Asian & 4 & 2 & 3 & 5 & 5 \\
\hline Other & 2 & 1 & 3 & 3 & 2 \\
\hline Hispanic origin & $15 \%$ & $10 \%$ & $9 \%$ & $20 \%$ & $13 \%$ \\
\hline \multicolumn{6}{|l|}{ Gender } \\
\hline Male & $48 \%$ & $48 \%$ & $48 \%$ & $48 \%$ & $48 \%$ \\
\hline Female & 52 & 52 & 52 & 52 & 52 \\
\hline \multicolumn{6}{|l|}{ Marital Status } \\
\hline Married & $67 \%$ & $67 \%$ & $68 \%$ & $67 \%$ & $66 \%$ \\
\hline Not Married & 33 & 33 & 32 & 33 & 34 \\
\hline \multicolumn{6}{|l|}{ Health Status } \\
\hline Share with fair or poor health & $11 \%$ & $11 \%$ & $12 \%$ & $11 \%$ & $10 \%$ \\
\hline \multicolumn{6}{|l|}{ Health Status 50+ } \\
\hline Share with fair or poor health & $18 \%$ & $18 \%$ & $19 \%$ & $19 \%$ & $16 \%$ \\
\hline \multicolumn{6}{|l|}{ Education } \\
\hline Less than high school & $5 \%$ & $6 \%$ & $3 \%$ & $6 \%$ & $4 \%$ \\
\hline High school & 39 & 46 & 41 & 38 & 36 \\
\hline Some college & 27 & 22 & 29 & 28 & 25 \\
\hline College graduates & 29 & 26 & 26 & 28 & 34 \\
\hline \multicolumn{6}{|l|}{ Education $50+$} \\
\hline Less than high school & $6 \%$ & $9 \%$ & $4 \%$ & $7 \%$ & $5 \%$ \\
\hline High school & 41 & 50 & 43 & 38 & 37 \\
\hline Some college & 25 & 18 & 28 & 27 & 24 \\
\hline College graduates & 28 & 22 & 25 & 28 & 34 \\
\hline \multicolumn{6}{|l|}{ Income/wealth } \\
\hline Average annual earnings & $\$ 37,800$ & $\$ 35,718$ & $\$ 36,969$ & $\$ 36,715$ & $\$ 42,185$ \\
\hline Average household income & $\$ 44,997$ & $\$ 42,813$ & $\$ 43,084$ & $\$ 43,783$ & $\$ 50,611$ \\
\hline Average small firm earnings & $\$ 36,020$ & $\$ 32,130$ & $\$ 36,629$ & $\$ 35,113$ & $\$ 40,088$ \\
\hline \multicolumn{6}{|l|}{ Employment } \\
\hline Employed & $77 \%$ & $77 \%$ & $77 \%$ & $77 \%$ & $78 \%$ \\
\hline Employed- small firm & 42 & 41 & 40 & 43 & 43 \\
\hline Employed- FT & 86 & 86 & 86 & 86 & 85 \\
\hline Employed- small firm, FT & 34 & 33 & 33 & 35 & 34 \\
\hline Age & 41.9 & 40.9 & 42.2 & 41.8 & 42.3 \\
\hline Age $50+$ & $26 \%$ & $23 \%$ & $27 \%$ & $26 \%$ & $27 \%$ \\
\hline $\begin{array}{l}\text { Covered by employer-sponsored } \\
\text { health insurance }\end{array}$ & $49 \%$ & $52 \%$ & $50 \%$ & $48 \%$ & $50 \%$ \\
\hline Sample size & $2,150,047$ & 345,552 & 391,545 & 941,465 & 471,485 \\
\hline
\end{tabular}


Table 3. Regression Results Estimating Employment Outcomes, 1989-2013

\begin{tabular}{|c|c|c|c|c|}
\hline & $(1)$ & \multicolumn{2}{|c|}{$(2)$} & (3) \\
\hline & $\begin{array}{c}\text { Overall } \\
\text { employment }\end{array}$ & \multicolumn{2}{|c|}{ Multinomial logit, firm size } & Small firm employment \\
\hline & & Small & Unemployed & \\
\hline \multirow{2}{*}{ Rate band } & $-0.01 * * *$ & -0.002 & $0.01 * * *$ & -0.002 \\
\hline & $(0.00)$ & $(0.00)$ & $(0.00)$ & $(0.00)$ \\
\hline \multirow{2}{*}{ Rate-band ratio } & 0.004 & 0.001 & $-0.01 * * *$ & 0.001 \\
\hline & $(0.00)$ & $(0.01)$ & $(0.00)$ & $(0.01)$ \\
\hline \multirow{2}{*}{$50+$} & $-0.12 * * *$ & $-0.02 * * *$ & $0.11^{* * *}$ & $-0.02 * * *$ \\
\hline & $(0.00)$ & $(0.00)$ & $(0.00)$ & $(0.00)$ \\
\hline \multirow{2}{*}{ Ratio*50+ } & $0.03 * * *$ & -0.002 & $-0.04^{* * *}$ & -0.002 \\
\hline & $(0.00)$ & $(0.00)$ & $(0.00)$ & $(0.00)$ \\
\hline Sample size & $2,150,047$ & \multicolumn{2}{|c|}{$2,150,047$} & $1,660,188$ \\
\hline R-squared & 0.06 & \multicolumn{2}{|c|}{0.04} & 0.03 \\
\hline
\end{tabular}

Note: Statistically significant at 10 -percent $(*)$, 5-percent $(* *)$, or 1-percent level $\left({ }^{* *}\right)$. Includes state and year fixed effects and controls for demographic variables such as gender, household income, education, race, Hispanic origin, marital status, and state unemployment rate. These results exclude observations of those living in Hawaii. Source: Authors' calculations from the CPS. 
Table 4. Earnings Regression Results, 1989-2013

\begin{tabular}{lcc}
\hline & $(1)$ & $(2)$ \\
\cline { 2 - 3 } & $\begin{array}{c}\text { No state } \\
\text { fixed effects }\end{array}$ & $\begin{array}{c}\text { State fixed } \\
\text { effects }\end{array}$ \\
\hline Rate band & $-0.17^{* * *}$ & 0.01 \\
Rate-band ratio & $(0.00)$ & $(0.01)$ \\
& $0.20^{* * *}$ & $-0.07^{* * *}$ \\
Small firm & $(0.01)$ & $(0.01)$ \\
& $-0.34^{* * *}$ & $-0.34^{* * *}$ \\
50+ & $(0.00)$ & $(0.00)$ \\
Ratio*Small firm & $0.12^{* * *}$ & $0.12^{* * *}$ \\
Ratio*50+ & $(0.00)$ & $(0.00)$ \\
& $0.07 * * *$ & $0.07^{* * *}$ \\
Small firm*50+ & $(0.01)$ & $(0.01)$ \\
& 0.005 & 0.000 \\
Ratio*Small firm*50+ & $(0.01)$ & $(0.01)$ \\
\hline Sample size & $-0.05^{* * *}$ & $-0.05^{* * *}$ \\
R-squared & $(0.01)$ & $(0.01)$ \\
\hline
\end{tabular}

Note: Statistically significant at the 1-percent level (***). Regression (2) includes state fixed effects. All regressions include year fixed effects and controls for demographic variables such as gender, household income, education, race, Hispanic origin, marital status, and state unemployment rate. These results exclude observations of those living in Hawaii. Does not include health status controls.

Source: Authors' calculations from CPS. 
Table 5. Regressions by Educational Attainment, 1989-2013

\begin{tabular}{|c|c|c|c|}
\hline & $\frac{(1)}{\text { Emplovment }}$ & $\frac{(2)}{\text { Small firm emplovment }}$ & $\frac{(3)}{\text { Earninos }}$ \\
\hline & Employment & & Earnings \\
\hline \multicolumn{4}{|l|}{ Less than high school } \\
\hline Rate band & $\begin{array}{r}0.02 \\
(0.02)\end{array}$ & $\begin{array}{r}-0.003 \\
(0.02)\end{array}$ & $\begin{array}{l}0.11^{* *} \\
(0.05)\end{array}$ \\
\hline Rate-band ratio & $\begin{array}{l}0.04^{* *} \\
(0.02)\end{array}$ & $\begin{array}{r}-0.01 \\
(0.03)\end{array}$ & $\begin{array}{l}-0.26 * * * \\
(0.06)\end{array}$ \\
\hline $50+$ & $\begin{array}{l}-0.08 * * * \\
(0.01)\end{array}$ & $\begin{array}{l}-0.05^{* * *} \\
(0.01)\end{array}$ & $\begin{array}{l}0.24^{* * * *} \\
(0.03)\end{array}$ \\
\hline Ratio*50+ & $\begin{array}{l}-0.03^{* * *} \\
(0.01)\end{array}$ & $\begin{array}{r}-0.01 \\
(0.02)\end{array}$ & $\begin{array}{l}-0.14^{* * *} \\
(0.05)\end{array}$ \\
\hline Small firm & & & $\begin{array}{l}-0.29 * * * \\
(0.02)\end{array}$ \\
\hline Ratio*Small firm & & & $\begin{array}{l}0.15^{* * * *} \\
(0.03)\end{array}$ \\
\hline Small firm*50+ & & & $\begin{array}{l}-0.14^{* * *} \\
(0.04)\end{array}$ \\
\hline Ratio*Small firm*50+ & & & $\begin{array}{r}0.08 \\
(0.06) \\
\end{array}$ \\
\hline Sample size & 106,539 & 62,229 & 62,229 \\
\hline R-squared & 0.14 & 0.04 & 0.12 \\
\hline \multicolumn{4}{|l|}{ High school only } \\
\hline Rate band & $\begin{array}{l}-0.02^{* * *} \\
(0.01)\end{array}$ & $\begin{array}{r}-0.01 \\
(0.01)\end{array}$ & $\begin{array}{l}0.04^{* * *} \\
(0.01)\end{array}$ \\
\hline Rate-band ratio & $\begin{array}{r}0.01 \\
(0.01)\end{array}$ & $\begin{array}{l}0.02^{* *} \\
(0.01)\end{array}$ & $\begin{array}{l}-0.14^{* * *} \\
(0.02)\end{array}$ \\
\hline $50+$ & $\begin{array}{l}-0.14^{* * *} \\
(0.00)\end{array}$ & $\begin{array}{l}-0.03^{* * *} \\
(0.00)\end{array}$ & $\begin{array}{l}0.10^{* * * *} \\
(0.01)\end{array}$ \\
\hline Ratio*50+ & $\begin{array}{l}0.04^{* * * *} \\
(0.00)\end{array}$ & $\begin{array}{l}-0.01^{* *} \\
(0.01)\end{array}$ & $\begin{array}{l}0.03^{* *} \\
(0.01)\end{array}$ \\
\hline Small firm & & & $\begin{array}{l}-0.36 * * * \\
(0.01)\end{array}$ \\
\hline Ratio*Small firm & & & $\begin{array}{l}0.13^{* * *} \\
(0.01)\end{array}$ \\
\hline Small firm*50+ & & & $\begin{array}{l}-0.04^{* * *} \\
(0.01)\end{array}$ \\
\hline Ratio*Small firm*50+ & & & $\begin{array}{r}0.002 \\
(0.02) \\
\end{array}$ \\
\hline Sample size & 845,890 & 613,963 & 613,963 \\
\hline R-squared & 0.04 & 0.02 & 0.13 \\
\hline
\end{tabular}


Table 5. Regressions by Educational Attainment, 1989-2013 (cont’d)

\begin{tabular}{|c|c|c|c|}
\hline & $(1)$ & $(2)$ & $(3)$ \\
\hline & Employment & Small firm employment & Earnings \\
\hline \multicolumn{4}{|l|}{ Some college } \\
\hline Rata hand & -0.01 & $0.02 * *$ & 0.002 \\
\hline Rate band & $(0.01)$ & $(0.01)$ & $(0.02)$ \\
\hline Data hond ratio & -0.01 & $-0.03 * *$ & $-0.08 * * *$ \\
\hline Rate-Dana ratıo & $(0.01)$ & $(0.01)$ & $(0.02)$ \\
\hline $50+$ & $-0.11 * * *$ & $-0.01 * *$ & $0.13 * * *$ \\
\hline $50+$ & $(0.00)$ & $(0.00)$ & $(0.01)$ \\
\hline Ratio*50+ & $0.02 * * *$ & $-0.01 * *$ & 0.004 \\
\hline & $(0.01)$ & $(0.01)$ & $(0.02)$ \\
\hline Small firm & & & $\begin{array}{l}-0.34^{* * * *} \\
(0.01)\end{array}$ \\
\hline Ratio*Small firm & & & $\begin{array}{l}0.07 * * * \\
(0.01)\end{array}$ \\
\hline Small firm*50+ & & & $\begin{array}{l}-0.04^{* *} \\
(0.02)\end{array}$ \\
\hline Ratio*Small firm*50+ & & & $\begin{array}{r}0.02 \\
(0.03)\end{array}$ \\
\hline Sample size & 577,944 & 461,173 & 461,173 \\
\hline R-squared & 0.03 & 0.01 & 0.12 \\
\hline \multicolumn{4}{|l|}{ College+ } \\
\hline Rate band & $\begin{array}{l}-0.03^{* * *} \\
(0.01)\end{array}$ & $\begin{array}{l}-0.02^{* *} \\
(0.01)\end{array}$ & $\begin{array}{c}-0.01 \\
(0.01)\end{array}$ \\
\hline Rate-band ratio & $\begin{array}{l}0.02^{* * *} \\
(0.01)\end{array}$ & $\begin{array}{l}0.02 * * \\
(0.01)\end{array}$ & $\begin{array}{r}0.01 \\
(0.02)\end{array}$ \\
\hline $50+$ & $\begin{array}{l}-0.08 * * * \\
(0.00)\end{array}$ & $\begin{array}{l}0.02^{* * *} \\
(0.00)\end{array}$ & $\begin{array}{l}0.12^{* * * *} \\
(0.01)\end{array}$ \\
\hline Ratio*50+ & $\begin{array}{l}0.01^{* * *} \\
(0.00)\end{array}$ & $\begin{array}{l}-0.01^{*} \\
(0.01)\end{array}$ & $\begin{array}{r}-0.01 \\
(0.01)\end{array}$ \\
\hline Small firm & & & $\begin{array}{l}-0.32^{* * *} \\
(0.01)\end{array}$ \\
\hline Ratio*Small firm & & & $\begin{array}{r}0.02 \\
(0.01)\end{array}$ \\
\hline Small firm*50+ & & & $\begin{array}{l}-0.05^{* *} \\
(0.02)\end{array}$ \\
\hline Ratio*Small firm*50+ & & & $\begin{array}{l}0.032 \\
(0.03)\end{array}$ \\
\hline Sample size & 619,674 & 522,823 & 522,823 \\
\hline R-squared & 0.04 & 0.01 & 0.12 \\
\hline
\end{tabular}

Note: Statistically significant at 10 -percent $(*)$, 5-percent $(* *)$, or 1-percent level $(* * *)$.

Source: Authors' calculations from the CPS. 
Figure 1. Average Predicted Employment Rate by Rate Band Strength and Age, 1989-2013

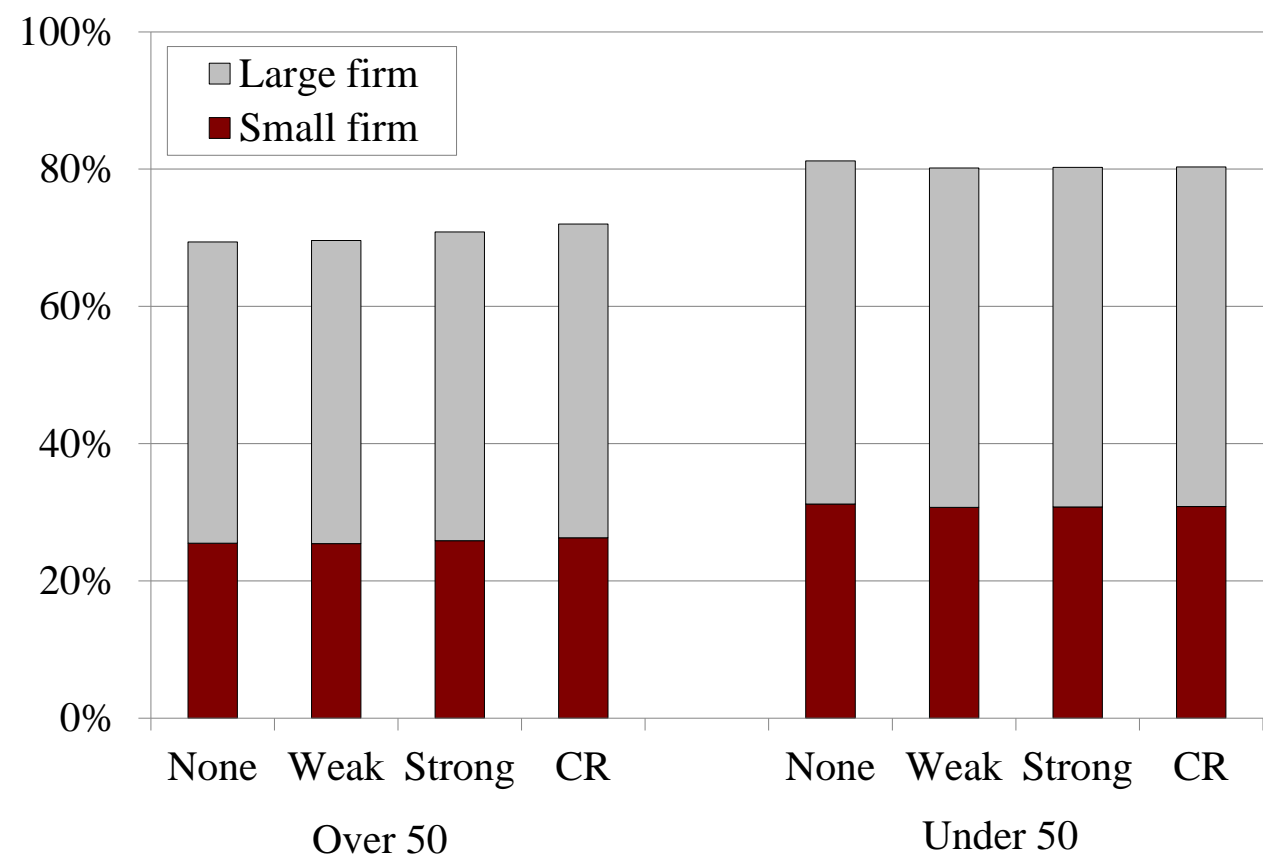

Notes: "Community rating" refers to a 1:1 rate-band ratio, "Strong" includes ratios between 1.2:1 and 1.67:1, and "Weak" includes ratios between 1.86:1 and 4:1. Includes year fixed effects and demographic variables such as education, race, and marital status. These results exclude observations of those living in Hawaii. Does not include health status controls. All other variables are assigned their sample mean.

Source: Authors' calculations based on data from the CPS. 
Figure 2. Predicted Gap between Average Large and Small Firm Earnings, by Age Group and Rate Band Strength, 1989-2013

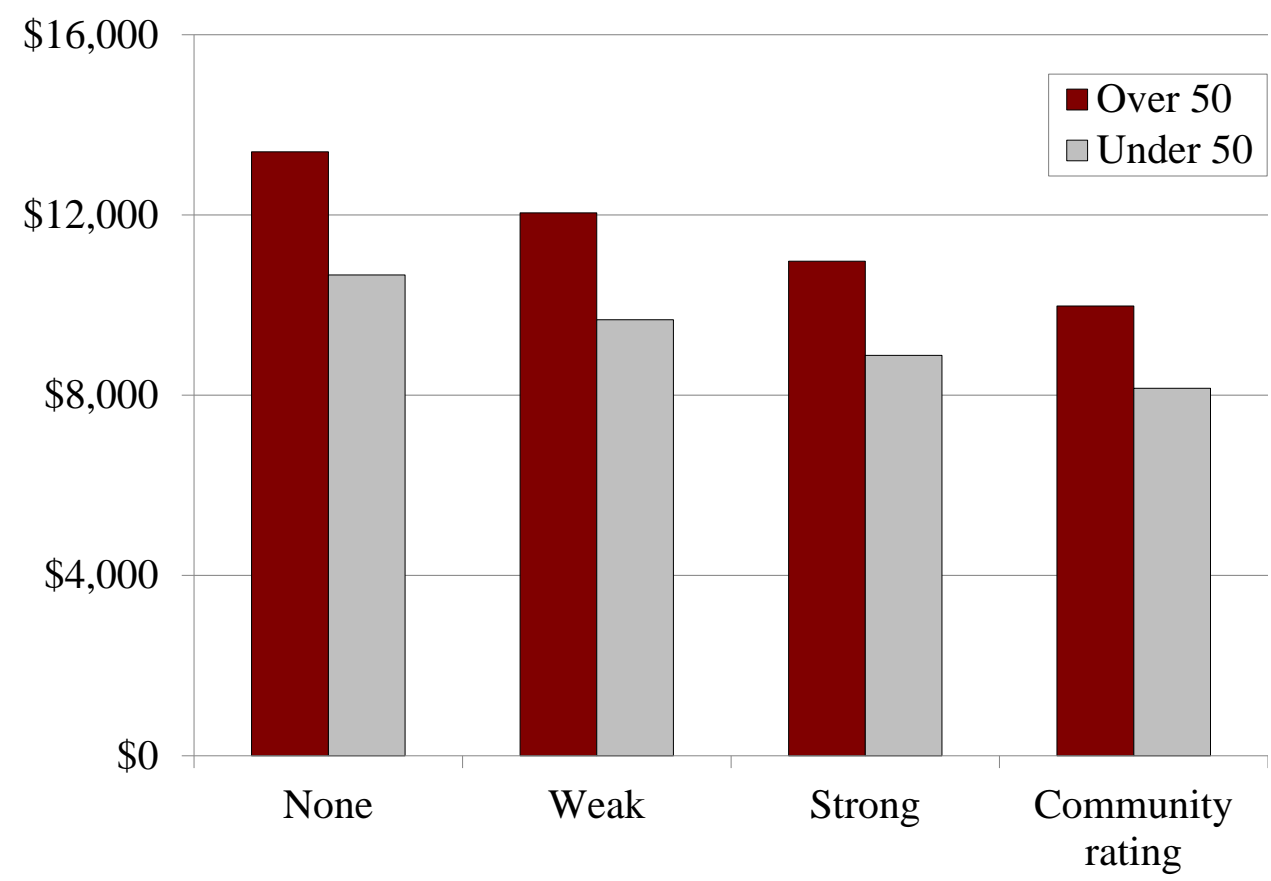

Notes: "Community rating” refers to a 1:1 rate-band ratio, "Strong” includes ratios between 1.2:1 and 1.67:1, and "Weak" includes ratios between 1.86:1 and 4:1. Includes year fixed effects and demographic variables such as education, race, and marital status. These results exclude observations of those living in Hawaii. Does not include health status controls. All other variables are assigned their sample mean.

Source: Authors' calculations based on data from the CPS. 
Table A1. Regression Results Estimating Employment Outcomes, 1995-2013

\begin{tabular}{lccc}
\hline & $(1)$ & $(2)$ & $(3)$ \\
\hline Rate band & $-0.02^{* * *}$ & $-0.02^{* * *}$ & $-0.02^{* * *}$ \\
Rate-band ratio & $(0.01)$ & $(0.00)$ & $(0.00)$ \\
& 0.01 & $0.02^{* *}$ & 0.01 \\
$50+$ & $(0.01)$ & $(0.01)$ & $(0.01)$ \\
& $-0.11^{* * *}$ & $-0.06^{* * *}$ & $-0.06^{* * *}$ \\
Ratio*50+ & $(0.00)$ & $(0.00)$ & $(0.00)$ \\
& $0.02^{* * *}$ & & $0.01^{* * *}$ \\
Unhealthy & $(0.00)$ & & $(0.00)$ \\
& & $-0.35^{* * *}$ & $-0.32^{* * *}$ \\
Ratio*Unhealthy & & $(0.00)$ & $(0.01)$ \\
& & $0.03^{* * *}$ & $0.03^{* * *}$ \\
Unhealthy*50+ & & $(0.01)$ & $(0.01)$ \\
& & & $-0.06^{* * *}$ \\
Ratio*Unhealthy*50+ & & & $(0.01)$ \\
\hline Sample size & $1,720,257$ & $1,720,257$ & $-0.02^{*}$ \\
R-squared & 0.06 & 0.12 & $(0.01)$ \\
\hline
\end{tabular}

Note: Statistically significant at 10-percent $(*)$, 5-percent $(* *)$, or 1-percent level $(* * *)$. Includes state and year fixed effects and controls for demographic variables such as gender, household income, education, race, Hispanic origin, marital status, and state unemployment rate. These results exclude observations of those living in Hawaii. CPS health status variable is only available from 1995 forward.

Source: Authors' calculations from the CPS. 
Table A2. Regression Results Estimating Small or Large Firm Employment, Conditional on Any Employment, 1995-2013

\begin{tabular}{lccc}
\hline & $(1)$ & $(2)$ & $(3)$ \\
\hline Rate band & 0.01 & 0.01 & 0.01 \\
& $(0.01)$ & $(0.01)$ & $(0.01)$ \\
Rate-band ratio & -0.01 & -0.01 & 0.00 \\
& $(0.01)$ & $(0.01)$ & $(0.01)$ \\
$50+$ & $-0.01^{* * *}$ & $-0.02 * * *$ & $-0.01^{* * *}$ \\
& $(0.00)$ & $(0.00)$ & $(0.00)$ \\
Ratio*50+ & $-0.01^{* *}$ & & $-0.01 * *$ \\
& $(0.00)$ & & $(0.00)$ \\
Unhealthy & & $0.02^{* * *}$ & $0.03^{* * *}$ \\
& & $(0.01)$ & $(0.01)$ \\
Ratio*Unhealthy & & -0.01 & -0.01 \\
& & $(0.01)$ & $(0.01)$ \\
Unhealthy*50+ & & & -0.01 \\
& & & $(0.01)$ \\
Ratio*Unhealthy*50+ & & & -0.002 \\
& & & $(0.02)$ \\
Sample size & $1,330,099$ & $1,330,099$ & $1,330,099$ \\
R-squared & 0.03 & 0.03 & 0.03 \\
\hline
\end{tabular}

Notes: Statistically significant at 10-percent $(*)$, 5-percent $(* *)$, or 1-percent level (***). Includes state and year fixed effects and controls for demographic variables such as gender, household income, education, race, Hispanic origin, marital status, and state unemployment rate. These results exclude observations of those living in Hawaii. CPS health status variable is only available from 1995 forward.

Source: Authors' calculations from CPS 
Table A3. Earnings Regression Results, with Health Status, 1995-2013

\begin{tabular}{|c|c|c|c|}
\hline & (1) & (2) & (3) \\
\hline Rate band & $\begin{array}{l}-0.04^{* * *} \\
(0.01)\end{array}$ & $\begin{array}{l}-0.04^{* * *} \\
(0.01)\end{array}$ & $\begin{array}{l}-0.04^{* * *} \\
(0.01)\end{array}$ \\
\hline Rate-band ratio & $\begin{array}{r}-0.01 \\
(0.02)\end{array}$ & $\begin{array}{r}-0.002 \\
(0.02)\end{array}$ & $\begin{array}{l}0.000 \\
(0.02)\end{array}$ \\
\hline Small firm & $\begin{array}{l}-0.27 * * * \\
(0.01)\end{array}$ & $\begin{array}{l}-0.27^{* * *} \\
(0.01)\end{array}$ & $\begin{array}{l}-0.26^{* * *} \\
(0.01)\end{array}$ \\
\hline $50+$ & $\begin{array}{l}0.12^{* * *} \\
(0.01)\end{array}$ & $\begin{array}{l}0.12^{* * *} \\
(0.00)\end{array}$ & $\begin{array}{l}0.14^{* * *} \\
(0.01)\end{array}$ \\
\hline Ratio*Small firm & $\begin{array}{l}0.000 \\
(0.01)\end{array}$ & $\begin{array}{l}0.000 \\
(0.01)\end{array}$ & $\begin{array}{r}-0.004 \\
(0.01)\end{array}$ \\
\hline Ratio*50+ & $\begin{array}{c}-0.01 \\
(0.01)\end{array}$ & & $\begin{array}{r}-0.01 \\
(0.01)\end{array}$ \\
\hline Small firm*50+ & $\begin{array}{l}-0.05^{* * *} \\
(0.01)\end{array}$ & & $\begin{array}{l}-0.04^{* * *} \\
(0.01)\end{array}$ \\
\hline Ratio*Small firm*50+ & $\begin{array}{r}0.01 \\
(0.02)\end{array}$ & & $\begin{array}{r}0.02 \\
(0.02)\end{array}$ \\
\hline Unhealthy & & $\begin{array}{l}-0.35^{* * *} \\
(0.02)\end{array}$ & $\begin{array}{l}-0.37 * * * \\
(0.02)\end{array}$ \\
\hline Ratio*Unhealthy & & $\begin{array}{r}0.03 \\
(0.02)\end{array}$ & $\begin{array}{c}0.05 * \\
(0.03)\end{array}$ \\
\hline Small firm*Unhealthy & & $\begin{array}{l}-0.07^{* *} \\
(0.03)\end{array}$ & $\begin{array}{l}-0.07^{* *} \\
(0.03)\end{array}$ \\
\hline Ratio*Small firm*Unhealthy & & $\begin{array}{l}0.002 \\
(0.04)\end{array}$ & $\begin{array}{r}0.03 \\
(0.05)\end{array}$ \\
\hline Unhealthy*50+ & & & $\begin{array}{c}0.06^{*} \\
(0.03)\end{array}$ \\
\hline Small firm*Unhealthy*50+ & & & $\begin{array}{r}0.02 \\
(0.05)\end{array}$ \\
\hline Ratio*Unhealthy*50+ & & & $\begin{array}{r}-0.06 \\
(0.05)\end{array}$ \\
\hline Ratio*Small firm*Unhealthy*50+ & & & $\begin{array}{r}-0.07 \\
(0.08) \\
\end{array}$ \\
\hline Sample size & $1,330,099$ & $1,330,099$ & $1,330,099$ \\
\hline R-squared & 0.21 & 0.21 & 0.21 \\
\hline
\end{tabular}

Notes: Statistically significant at 10-percent $(*)$, 5-percent $(* *)$, or 1 -percent level $(* * *)$. Includes state and year fixed effects and controls for demographic variables such as gender, household income, education, race, Hispanic origin, marital status, and state unemployment rate. These results exclude observations of those living in Hawaii. CPS health status variable is only available from 1995 forward, therefore results are presented for 1995-2013. Source: Authors' calculations from the CPS. 


\section{Appendix A. State Laws Pertaining to Small-Group Premium Rate Restrictions}

Alabama Insurance Reg. § 482-1-116-.05

Alaska Stat. § 21-56-120

Arizona Rev. Stat. § 20-2311

Arkansas Code $\S 23-86-204$

California Insurance Code $\S 10714$

Colorado Rev. Stat. § 10-16-105(8.5)

Connecticut Gen. Stat. § 38a-567

Delaware Code Title 18 § 7205

District of Columbia Code § 31-3311.02

Florida Stat. § 627.6699(6)

Georgia Code § 33-30-12

Hawaii Rev Stat. § 393

Idaho Code $\S 41-4706$

215 ILCS (Illinois Compiled Statutes) 93/25

Indiana Code $\S 27-8-15-16$

Iowa Code $\S 513$ B. 4

Kansas Stat. § 40-2209h

Kentucky Rev. Stat. § 304.17A-0952

Louisiana Rev. Stat. § 22:228.6

Louisiana Rev. Stat. § 22:1095

Maine Rev. Stat. Tit. 24-A § 2808-B

Maryland Insurance Code § 15-1205

Massachusetts General Laws Ch. 176J § 3

Michigan Comp. Laws § 500.3705

Minnesota Stat. § 62L.08

Mississippi Code § 83-63-7

Missouri Stat. § 379.936

Montana Code Ann. § 33-12-1809

Nebraska Rev. Stat. § 44-5258

Nevada Rev. Stat. § 689C.230

New Hampshire Rev. Stat. Ann. § 420-G:4

New Jersey Stat. Ann. § 17B:27A-25

New Mexico Stat. § 59A-23C

New York Insurance Law § 3231

North Carolina Gen. Stat. Ann. § 58-50-130

North Dakota Century Code § 26.1-36.3

Ohio Rev. Code $\S 3924$

Oklahoma Code § 36-6515

Oregon Rev. Stat. § 743.737 
Pennsylvania Code $31 \S 89.83$

Rhode Island Gen. Laws § 27-50-5

South Carolina Code Ann. § 28-71-940

South Dakota Codified Laws § 58-18B-3

Tennessee Code Ann. § 56-7-2209

Texas Insurance Code Ann. § 1501.204

Utah Code Ann. § 31A-30-106

Vermont Stat. Ann. Tit. $8 \S 4080$

Virginia Code § 38.2-3433

Washington Rev. Code § 48.21.045

West Virginia Code § 33-16D-5

Wisconsin Stat. § 635.05

Wyoming Stat. § 26-19-304 


\section{RECENT WORKING PAPERS FROM THE CENTER FOR RETIREMENT RESEARCH AT BOSTON COLLEGE}

An Overview of the Pension/OPEB Landscape

Alicia H. Munnell and Jean-Pierre Aubry, October 2016

What Are the Effects of Doubling Up on Retirement Income and Assets?

Deirdre Pfeiffer, Katrin B. Anacker, and Brooks Louton, September 2016

How Does Student Debt Affect Early-Career Retirement Saving?

Matthew S. Rutledge, Geoffrey T. Sanzenbacher, and Francis M. Vitagliano, September 2016

The Labor Supply of Disabled Veterans: 1995-2014

Matthew S. Rutledge, Geoffrey T. Sanzenbacher, and Caroline V. Crawford, August 2016

The Mortality Effects of Retirement: Evidence from Social Security Eligibility at Age 62 Maria D. Fitzpatrick and Timothy J. Moore, August 2016

How Would Investing in Equities Have Affected the Social Security Trust Fund?

Gary Burtless, Anqi Chen, Wenliang Hou, Alicia H. Munnell, and Anthony Webb, July 2016

Are Early Claimers Making a Mistake?

Alicia H. Munnell, Geoffrey T. Sanzenbacher, Anthony Webb, and Christopher M. Gillis, July 2016

Marital Histories, Gender, and Financial Security in Late Mid-Life: Evidence from Four Cohorts in the Health and Retirement Study

Amelia Karraker and Cassandra Dorius, July 2016

Pension Participation, Wealth, and Income: 1992-2010

Alicia H. Munnell, Wenliang Hou, Anthony Webb, and Yinji Li, July 2016

The Interconnected Relationships of Health Insurance, Health, and Labor Market Outcomes

Matthew S. Rutledge, July 2016

Labor Force Dynamics in the Great Recession and Its Aftermath: Implications for Older Workers

Gary Burtless, July 2016

The Economic Burden of Out-of-Pocket Medical Expenditures Before and After Implementation of the Medicare Prescription Drug Program

Ayse Akincigil and Karen Zurlo, November 2015

All working papers are available on the Center for Retirement Research website (http://crr.bc.edu) and can be requested by e-mail (crr@bc.edu) or phone (617-552-1762). 